\title{
COVID-19, instability and migrant fish workers in Asia
}

\author{
Melissa Marschke ${ }^{1}$ (1) $\cdot$ Peter Vandergeest ${ }^{2}$ - Elizabeth Havice ${ }^{3} \cdot$ Alin Kadfak $^{4} \cdot$ Peter Duker $^{2}$. \\ llinca Isopescu ${ }^{1} \cdot$ Mallory MacDonnell ${ }^{2}$
}

Received: 31 August 2020 / Accepted: 4 November 2020 / Published online: 23 November 2020

(C) Springer-Verlag GmbH Germany, part of Springer Nature 2020

\begin{abstract}
This paper seeks to establish how COVID-19 is impacting migrant fish workers through focusing on two global fish hubs, Thailand and Taiwan. Through a careful review of the news reports, social media, and NGO reports and press releases, three significant themes emerged: employment disruptions due to seafood system instabilities; travel or mobility restrictions; and poor access to services such as health care or social programs. We unpack each theme in turn to spotlight the impacts COVID-19 is having on yet another vulnerable worker population, fish workers. We further reflect on what this pandemic reveals about unacceptable work in industrial fisheries and consider if the pandemic may be producing opportunities to advocate for better working conditions.
\end{abstract}

Keywords Labour $\cdot$ Migration $\cdot$ Industrial fisheries $\cdot$ Seafood $\cdot$ Pandemic

\section{Introduction}

Work in industrial fisheries is unacceptably dangerous and poorly regulated (Vandergeest and Marschke 2020; Campling and Cólas 2021). Accidents at sea result from and are compounded by storms, vessels colliding, slipping on decks, bites from handling aquatic life, hypothermia or drowning and sheer physical fatigue (Jensen et al. 2014; Frantzeskou et al. 2016; Kaustell et al. 2016). The daily ecological rhythms that dictate the timing and pace of work often render it difficult to place clear limits on working hours (Belton et al. 2019). More insidiously, labour abuse across global fisheries, including Thailand, Taiwan and New Zealand, has been revealed through international media profiles and research by NGOs (HRW 2018; EJF 2019), resulting in a growing interest in and concern over labour conditions on fishing vessels (Couper et al. 2015; Marschke and Vandergeest 2016; Tickler et al. 2018). Two

Melissa Marschke

mmarschk@uottawa.ca

1 School of International Development and Global Studies, University of Ottawa, 120 University Private, Ottawa, ON K1N 6N5, Canada

2 York University, Toronto, Canada

3 University of North Carolina-Chapel Hill, Chapel Hill, USA

4 Swedish University of Agricultural Sciences, Uppsala, Sweden characteristics of fish work further complicate efforts to regulate and improve conditions in fish work: work takes place on the ocean and is difficult to monitor, and workers tend to be migrants performing work that few others want to do.

The challenges facing migrant fish workers are similar, in many ways, to that of migrant workers globally who are supplying labour within industrial food systems including meat plant workers, seafood processing, and seasonal or permanent agricultural farm workers. Migrant workers in the food system have long experienced precarious work and living conditions including the following: uncertain legal status, excessive working hours, unsafe working conditions, restrictions on mobility, limited to no access to health care, substandard and crowded housing, physical and psychological abuse, and mental health struggles. These conditions are enabled by racism, inadequate government workplace regulation and restrictions on the right to organize (e.g. Neef 2020; Basok and George 2020; Haley et al. 2020; Barndt 2004).

For migrant fish workers, COVID-19 has added another layer of vulnerabilities to this often invisible worker population. Their working and living conditions render them vulnerable to transmission of the virus. Racism and marginality have heightened the fear and suspicion that they might be a source of infection. Travel restrictions have increased vulnerability to exploitation, abuse, and mental health problems, and their precarious legal status and isolation at sea and in ports, combined with language barriers, undermine access to health care and emergency social security. 
For example, during the initial stages of the pandemic, migrant fish workers began to find themselves stranded at ports as the world went into lockdown or working at sea for longer than anticipated as boat owners evaded port quarantine measures. Some fish workers were denied emergency medical attention because of port shutdowns (Twining 2020). As the pandemic continued, outbreaks of COVID19 affected workers on industrial fishing boats, helping to make port authorities wary of fishing vessels. In May 2020, an outbreak among the crew on a Spanish trawler sparked intense debates within EU borders as to where the vessel should dock to enable medical treatment (Connolly 2020). COVID-19 outbreaks have since been found on an Ecuadorian purse seiner (Atuna 2020) and, in June 2020, on three American-owned, Seattle-based boats heading to Alaska (Herz 2020). Adding to this, fisheries management bodies temporarily removed requirements for fisheries observers on boats to lower the risk of COVID-19 spread and to keep fishing vessels operating (MSC 2020). Yet, the presence of fisheries observers on boats may help deter labour abuse.

This paper seeks to establish how COVID-19 is impacting migrant fish workers and to draw conclusions that contribute to the broader literature on labour and seafood in industrial fisheries (see Campling et al. 2012; Havice and Campling 2021; Howard 2012; Stringer et al. 2015; Havice and Campling 2021). We also contribute to the emerging research on health vulnerabilities among migrant workers in the food system. To do so, we focus on two global fish hubs, Thailand and Taiwan, building on our collective expertise on industrial fisheries in Asia (see Marschke and Vandergeest 2016; Havice et al. 2020; Vandergeest and Marschke 2020). We have carefully tracked the news and social media during January 2020 to August 2020, coding news articles, and identifying key themes. Several NGO reports and a handful of key informant interviews further informed our understanding. Fieldwork was not an option during the pandemic, so our review is reliant on the accuracy of media and other sources, and our methods did not allow us to learn directly from workers how they experienced the pandemic. Analysis of these data sources revealed three key impacts: employment disruptions due to seafood system instabilities; mobility restrictions due to COVID-19 management practices; and limits on access to services such as health care or social programs.

In the next sections, we first present background on Thailand and Taiwan's role in the global seafood industry and then outline our detailed findings. Finally, we further consider what this moment reveals about unacceptable work conditions in fisheries, and conversely, if there might also be some opportunities resulting from this COVID-19 pandemic to improve these conditions.

\section{Thailand and Taiwan in the global seafood industry}

Our discussion of COVID-19 and work in fishing is based on vessels owned and operated from Thailand and Taiwan. Workforces in both of these fisheries are composed almost entirely of migrant workers: workers travel primarily from Myanmar and Cambodia for the Thai fisheries and from Indonesia, Philippines and Vietnam for the Taiwanese fisheries. Both countries have been praised for how well they have managed the pandemic in terms of economic relief, health communication and use of travel restrictions (Bismonte 2020; Kornreich and Jin 2020), and both have had relatively few cases of COVID-19. However, examining the experiences of migrant fish workers in Thai and Taiwanese industrial fisheries during the first 6 months of the pandemic also reveals important problems for workers, even in countries that have managed the pandemic successfully.

As background, it is important to point out that measures designed to limit the spread of COVID-19 are particularly difficult to implement in industrial fisheries. It is near impossible to meet hygienic standards on fishing boats. Crowded working and living conditions on boats, or in ports with families, makes physical distancing impossible to practice (Venugopal 2020; Fawthrop 2020; Siamhan and Trirath 2020). Fresh water is limited and personal protective equipment (PPE) are generally not distributed (Siamhan and Trirath 2020), in part because PPE are difficult to endure in water- and sun-drenched fish work.

Seafood processing plants are also conducive to the spread of infection unless owners and operators implement significant measures to reduce transmission. These include physical distancing protocols or other forms of separation, and disinfection practices. Existing, non-COVID-19 food safety provisions mean that many processing facilities have experience in designing production practices to meet health and safety needs, in contrast to fishing boats (Rogovin 2020a). However, particularly at the outset of the pandemic, many seafood processing facilities needed to modify or temporarily halt production in order to implement additional health and safety measures. Production was thus slowed despite a general boom in demand for processed and shelf-stable seafood products, as maintaining both production volumes and intensified hygienic practices were a challenge (see, e.g., Mereghetti 2020a, 2020b, 2020c; Seaman 2020). COVID-19 exposures in processing and on vessels stand to impact each other, and particular dynamics vary from place to place. Additionally, COVID-19 has dramatically shifted demand in different seafood market segments: during the early months of the pandemic, supermarkets saw increased demand for fresh, frozen and shelf-stable seafood, while demand decreased dramatically for high-value fresh and frozen seafood sold in restaurants and other consumption sites outside the home. These 
upheavals were followed by uncertain and unstable partial recoveries in fresh/frozen seafood sales as economies reopened. In short, the entire seafood system has been disrupted by COVID-19 (Havice et al. 2020), in which Thailand and Taiwan are major players.

\section{Thai industrial fisheries}

In 2019, Thailand's industrial fishing fleet (Thailand classifies vessels sized more than 10 tonnes as commercial; we use the term industrial) officially consisted of 10,530 licenced vessels (Department of Fisheries, Government of Thailand 2019:6). These vessels use relatively labour-intensive technologies and operate primarily in Thailand's exclusive economic zone (EEZ). Most vessels (about $81 \%$ ) fish in the Gulf of Thailand, with the remainder working in the Andaman Sea. Official records indicate that commercial boats caught over 1,249,000 tonnes of seafood during 2019 (Department of Fisheries, Government of Thailand 2020a: 6). The government had issued about 20,000 licences for specific gears to these commercial vessels, meaning that most vessels had licences for more than one kind of gear. Of these, trawlers were the largest number at 3583 licences (about 18\% of gear licences, and $34 \%$ of vessels), while purse seine licences were also important. These two gears comprised $86 \%$ of the total marine catch as of 2012 (Department of Fisheries 2015: 15). Gill nets are important in the small-scale fisheries, while other gears include the usual assortment of mobile and fixed gears.

Trawlers target shrimp and other demersal species, but their most important product is so-called trash fish, estimated as around 50\% of the catch by weight (Department of Fisheries 2015: 12 - estimates vary from 40 to $60 \%$ ). Most is sold to mills producing animal feed, including for shrimp farms (Hodal et al. 2014). Important pelagic species targeted by the net-based gears include mackerel, anchovies, sardines, scad and tunas. The two most important are mackerel and anchovy. Most mackerels are consumed fresh as relatively affordable seafood, and this fishery is thus vulnerable to pandemic closures of restaurants and other prepared fresh food services. Most anchovies are processed into fish sauce. Overall, the bulk of the seafood caught by Thai vessels is consumed domestically: it is sold in large retail outlets, restaurants and other fresh food outlets, or supplied to feed mills, or converted into fish sauce, dried fish and other preserved foods. Although Thailand is also a major seafood exporter, most raw materials for these exports are imported (e.g. tuna), or produced by aquaculture operations (e.g. shrimp and tilapia). As an example, in May 2020, Thailand imported frozen tuna valued at over 49 million Thai baht (1,550,000 USD), and during the same month exported canned tuna valued at 54 million Thai baht $(1,717,000$ USD) (Department of Fisheries 2020b).
The estimated 55,000 workers on Thai vessels are among the millions of Cambodian, Myanmar and Lao workers who do the most difficult and marginalized work in Thailand (Rogovin 2020b). Working conditions in the Thailand-based fishing fleet has been the subject of intense international scrutiny since 2014, when The Guardian and many other news outlets and NGOs began to cover what they framed as 'slavery' in the Thai fisheries (Marschke and Vandergeest 2016). Working conditions in Thailand's offshore fisheries included extreme cases of violence, human trafficking (Issara and IJM 2017) and forced labour (ILO 2013, 2018) that were highlighted in media reports. More broadly, working conditions were very poor for many workers; workers experienced frequent physical and mental abuse, low wages, long working hours and a lack of legal status leading to vulnerabilities to police extortion or deportation (Derks 2010; EJF 2013). Widespread media coverage of cases of extreme abuse (Hodal et al. 2014; Urbina 2015), combined with a history of not enforcing fishing regulations, led to Thailand being issued a yellow card by the European Union for illegal, unreported and unregulated (IUU) fishing, and to other international actions including being downgraded in the US annual Trafficking in Persons (TIP) report. As a result of this international pressure, the Thai government and seafood corporations initiated a series of fisheries policy reforms that focused on improving labour conditions as well as on fisheries management. Changes to fisheries labour regulations were based on ILO C-188, the Work in Fishing Convention: in 2019, Thailand was the first country in Asia to ratify this convention.

Prior to Thailand's policy reforms, many Thailand-based vessels operated regionally.

These vessels often fished illegally or through dubious arrangements with local partners in fishing grounds under the jurisdiction of Indonesia and other Southeast Asian countries. Some larger owners also operated unregistered 'ghost fleets' in global waters, sustained by transshipment at sea practices (Greenpeace Southeast Asia 2016). The policy reforms have largely contained Thai-owned vessels to Thailand's Economic Exclusive Zone (EEZ), in part by requiring that all vessels over 30 tonnes instal Vessel Monitoring System (VMS) devices that enable the Thai fishing department to track their locations. In addition, all industrial fishing vessels are required to undergo port-based inspections both leaving and entering ports, in adherence to the international Agreement on State Port Measures which Thailand accepted in 2016. As a result, inspectors search all boats that leave from and return to port, including looking for signs of physical violence and appropriate documentation among workers. These labour reforms have improved working conditions, particularly in terms of reducing physical violence at sea and ensuring a minimum standard for wages in fish work. Even so, problems remain, including cursory inspections of workers in the presence of work 
supervisors; contracts are only written in Thai; legal obstacles to unionization; and in some cases, unpaid or unfairly deducted wages (CSO 2018; ILO 2020b).

Figure 1 displays a timeline of key moments, policies and market dynamics for the pandemic in Thailand and Taiwan. Thailand's first confirmed case of COVID-19 was in early January 2020, with the Thai government declaring the first closures (bars, cockfights, schools) on March 16. Partial border closures were announced March 18; checkpoints on the Myanmar border were closed on Monday, March 23; a draft regulation outlining employee compensations was issued on March 24; and a state of emergency was declared on March 25th, which confirmed many of the measures already in place (ILO Thailand 2020a; Fig. 1; various news items). Tourism, a major component of the economy especially along the Andaman coast and a major contributor to demand for high-value fresh seafood, was completely shut down. At some point (we are not sure when), during this chaotic period, the Thai government declared seafood to be an essential consumer good (Thongtub 2020) so that fishing could continue although not without challenges and modifications to production practices due to port restrictions and the loss of workers who left for Myanmar as the borders were closing. Thai boat owners are now struggling although their challenges may be as much to do with the fisheries policy reforms as the pandemic. For example, in August 2020, the National Thai Fisheries Association requested the Thai government to buy back at least 500 commercial fishing boats (to subsidize operational boats and bear the cost for unoperational boats) citing economic hardship due to IUU policies and COVID-19 (มติประชุมใหญ่ เลิกอาชีพประมง 2020).

\section{Taiwanese industrial fisheries}

Taiwan's fishing fleet can be divided into two sectors, one fishing in the Taiwanese Economic Exclusive Zone (EEZ) and the other in the distant water fishery (DWF). Taiwan's EEZ fisheries are comprised of vessels of varying size and gear, including trawlers, long-liners, drag net vessels and gill net vessels (Divovich et al. 2015). The DWF consists of around 1100 vessels (EJF 2019) flagged to Taiwan that move among fishing grounds located around the world. A majority of these vessels are tuna long-liners whose catch is destined primarily for international fresh/frozen seafood markets, including for sushi- and sashimi-grade products (Campling et al. 2017). Purse seine vessels target primarily tuna for canning in seafood processing centres, including Thailand, with limited quantities also being processed in Pacific Island countries (Havice et al. 2019). The remainder of the DWF fleet is made up of large industrial squid vessels. In addition to the approximately 1100 known vessels, an unknown number of DWF vessels are owned and operated from Taiwan but registered in other countries, sometimes to access particular national fishing grounds, and sometimes as flags of convenience to avoid government regulations including those concerning labour.

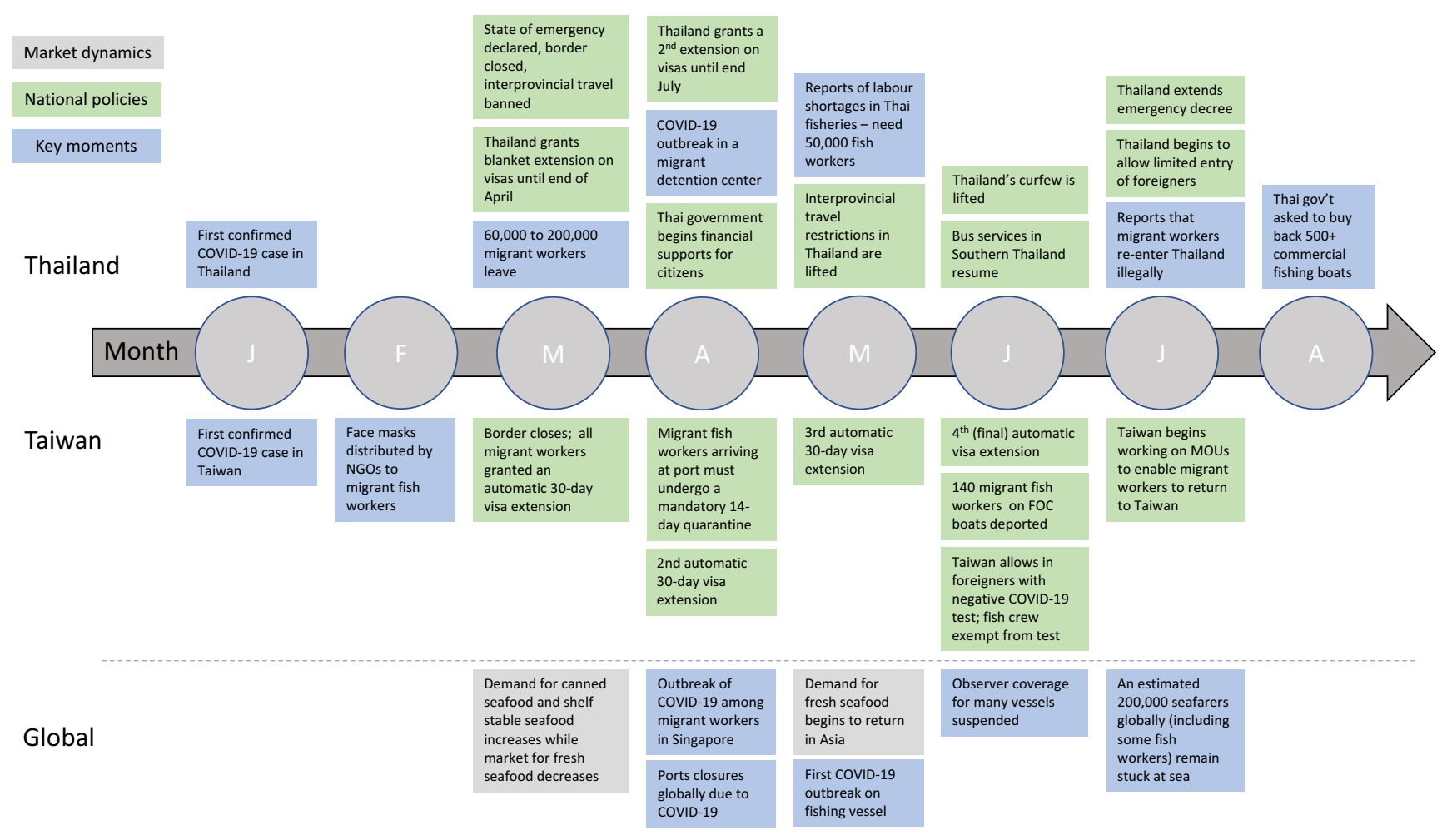

Fig. 1 A brief timeline of COVID-19 disruptions in fisheries 
Most workers in Taiwanese fisheries are recruited from Southeast Asia, a majority from Indonesia and also from the Philippines and Vietnam. Taiwan's two-tier system for government regulation of labour relations and working conditions in fisheries provides different protections to workers that are hired to fish in the EEZ compared with those hired to work on DWF vessels (Greenpeace East Asia 2020). Workers in the EEZ fisheries are registered and fall under Taiwanese labour laws as enforced by the Ministry of Labour. As of July 2019, some 12,000 workers were registered as working in the EEZ fisheries as 'foreign' fishers, about $75 \%$ from Indonesia (Chiang 2019:6). Migrant workers in the EEZ fishery tend to live on boats when in port to save on housing costs and to ensure someone is watching over the fishing vessels.

In contrast, workers in the DWF fisheries are recruited by, and sign contracts through, manning agencies in source countries. Until recently, the government of Taiwan did not take responsibility for labour relations or working conditions on DWF vessels registered in Taiwan, but under international pressure, including a yellow card from the European Union for failing to rein in IUU fishing, it finally enacted some regulations in 2017. The 2017 Distant Waters Fisheries Act includes requirements for a minimum wage, limits on wage deductions and health insurance. The Fisheries Agency was charged with enforcing these labour regulations. In practice, there is considerable evidence that enforcement of labour regulations continues to be poor and that DWF workers are subject to physical and mental abuse, lack of access to health care, unreasonable wage deduction by manning agencies, the withholding of wages and excessive working hours (Greenpeace East Asia 2020; EJF 2020). The situation of workers on vessels owned by Taiwan-based capital and registered to other countries may be even more difficult, as the relevant labour regulations and their enforcement vary depending on where these vessels are registered (Greenpeace East Asia 2020).

Similar to Thailand, Taiwan's first reported case of COVID-19 was in January 2020. Taiwan's response was rapid, with Taiwan emerging as a global leader in managing the COVID-19 pandemic (Kornreich and Jin 2020). The total number of reported cases remains less than 300 as we write this. The Taiwan government was able to avoid closing down restaurants and other venues selling fresh seafood, and even schools remained open. Instead, the government mandated intensive monitoring policies, quarantines, cell phone tracking, temperature checks and limits on numbers of customers in restaurants (Sui 2020). Even so, as seen in other countries including Singapore and Canada, Taiwan's prevention strategies did not immediately focus on migrant workers. Fish workers from both the EEZ and DWF expressed concerns about their health and safety in light of the pandemic (Cheung 2020), particularly in the early days, while advocacy organizations emphasized that fish workers in Taiwan's DWF are particularly at risk, for reasons we outline below.

\section{Emerging challenges for fish workers under COVID-19}

Based on our review of media and other sources, we have identified three types of challenges for fish workers in Thai and Taiwanese fisheries: a destabilized seafood system, restrictions on travel and port access, and access to health care and emergency medical services. In what follows, we review the significant findings for each.

\section{A destabilized seafood system}

We start with considering how COVID-19 disruptions in seafood supply chains impacted fishing, fish work and fish workers. Where specific data on this is still lacking, we note the likely impact based on what we do know. In Thailand, information on the changing operations of fishing vessels is scarce, but sources suggest that vessels that primarily supply fresh seafood markets went through a period having difficulties selling their seafood product(s). NGO websites and personal accounts give examples of efforts to make up for lost markets through increasing direct and online sales, although these were primarily in support of smaller-scale fisheries. We also assume that vessels (especially trawlers and anchovy purse seiners) that primarily supply raw materials for processed seafood or for animal feed continued to find buyers, although initial reports indicate that seafood processing did slow down in order to make changes to limit the spread of the virus. Restaurants, malls and so on were gradually allowed to re-open by May 2020, with restrictions, presumably reestablishing some demand for fresh seafood.

The DWF fisheries based in Taiwan was also been differentially impacted depending on whether vessels supply fresh/ frozen or processed seafood markets. For example, by the end of April 2020, the Fong Chun Formosa company, a top-three global tuna trader that owns many large fishing vessels supplying major brands (Greenpeace East Asia 2020), saw a rising demand for tuna caught on their purse seine vessels that was destined for canning. This was temporarily offset, however, by slowdowns in tuna processing plants located in Papua New Guinea, Thailand, Mauritius and China, due to the introduction of pandemic management policies (Aqorau 2020). At the same time, demand for fresh/frozen seafood for high-value auction and retail outlets dropped, which impacted the longliners that supply these markets. The reopening of Chinese markets in the Spring of 2020 for fresh/frozen seafood may have eased some of these bottlenecks, although recent evidence that the COVID-19 virus can survive on frozen foods for several weeks, and may even have been responsible for several outbreaks in Asia, might lead to new slowdowns in seafood trade and retailing (Fisher et al. 2020).

Demand cycles were not the only source of disruptions in seafood systems. COVID-19 also impacted supply dynamics 
by creating new hurdles for vessels, the base of seafood supply chains, to operate and offload catches during the initial months of the pandemic. Boats had to wait for new policies relating to observer status, ports were shut down and reopened and extended quarantine policies rendered some ports difficult or impossible to access. We expand further below.

\section{Restrictions on travel and port access}

In Thailand, the experiences of migrant fish workers varied widely in the chaotic, rapidly shifting early days of the pandemic. This was a period of extreme uncertainty for migrant workers, and it was unclear which services would be deemed as essential. The phased border closures in March (above) thus triggered a rapid exodus of migrant workers (Fig. 1). Between 60,000 and 200,000 migrant workers from Myanmar, Laos and Cambodia left Thailand during the week of March 18 when border closures were announced for the following week (Rogovin 2020a). As Thailand shut down, many migrant workers lost their jobs or left as they wanted to be with their families during the pandemic. Those who stayed - whether by choice or due to travel restrictions - faced significant challenges as employers reduced or shut down operations (Heidler 2020; Thaw and Dunant 2020), and as government programs to compensate workers who lost income were being formulated. Support organizations in Thailand (LPN, MWRN etc.) turned to raising funds to provide unemployed seafood workers with food (Facebook postings; ILO 2020b: 10).

Paradoxically, as fishing resumed, owners and captains in some ports found themselves unable to find workers, since many migrant fish workers left when Thailand's borders closed (Xinhua News Agency 2020). Pandemic policies may have intersected with fisheries management policies in ways that also led to worker shortages. For example, a three-month fishing ban was imposed in February 2020 in the Gulf of Thailand waters adjacent to three provinces: workers who left ports in these provinces at this time (CTN News 2020) would have been unable to return. Worker shortages were further compounded by restrictions on travel among ports, due to a ban on public transportation including on interprovincial bus travel. Workers, out of work in one area, could not move to fill labour gaps elsewhere until these restrictions were loosened in mid-May (Zaw 2020). Bus services in the South, where most ports are located, reportedly did not resume until the end of June. In addition, fishing vessels were not permitted to move among different ports (Thongtub 2020; National News Bureau of Thailand 2020). These restrictions meant that some fishing vessels became stranded in other provinces or even other countries (Thongtub 2020; ลูกเรือประมง 22 ชีวิตกลับจากออกเรือหาปลาในมาเลเซีย ยอมกักต้วเอง 14 วัน 2020). This shortage of workers may have given workers an opportunity to improve their situations. For example, observers in
Thailand have told us that some workers have been able to negotiate higher wages.

By July, four months after the border shut down, there were news stories of migrant workers paying labour brokers to reenter Thailand illegally (จับ44แรงงานพม่าลอบเข้าเมือง 2020). Meanwhile, the Thai government and the private sector were in discussions about who should bear the costs of COVID-19 testing and the 14-day mandatory quarantine for anyone entering Thailand. The costs of such quarantine measures are estimated to be around 19,300 THB (just over 600 USD per worker), a prohibitive cost for migrant workers (นายจ้างขอรัฐแบ่งเบา ค่าตรวจโรค-กักต้ว นำเข้าแรงงานเพือนบ้าน 2020). These costs may push boat owners to hire workers illegally, leaving workers more vulnerable to exploitation and limiting their access to social security. Finally, there are reports that restrictions on border crossings have prevented workers in ports nearer Myanmar from returning home during their breaks of two to three days between fishing trips and that boat owners have taken advantage by requiring their workers to work longer hours, more days, and forcing workers to stay on the fishing boats with their poor living conditions.

In Taiwan, travel restrictions also had an immediate impact on migrant workers, including fish workers. By March 2020, the Taiwanese government was encouraging employers to draw from Taiwan's existing labour pool of migrant workers, since cross-border arrivals for newly hired workers had been halted. Between late March and late June, over 80,000 migrant workers (all workers, not just fish workers) who were already in Taiwan applied for a new job or were re-hired (Tzu-ti 2020), being granted an extension on their visas (Everington 2020). While this enabled workers to continue working in Taiwan legally, this also meant that workers were also essentially 'stuck' working in Taiwan. Only in July 2020 did the Indonesian and Taiwanese governments begin working on an MOU to enable workers to return to Taiwan, including fish workers (Hsiu-chuan and Yeh 2020). As in Thailand, some of the fish workers who remained in Taiwan were reportedly able to negotiate higher salaries given the overall worker shortage. The terms and conditions of fish work under COVID-19 constraints on mobility requires detailed follow-up.

Migrant workers in the DWF may be stuck on vessels, at sea, or in ports if they are unable to return home at the end of a contract due to travel restrictions at ports or a lack of commercial flights. As of early July 2020, an estimated 200,000 seafarers were stuck at sea (Ha et al. 2020), increasing to an estimated 400,000 by late September (IMO 2020). Most are workers on cruise and merchant ships, but they also include DWF workers. Human Rights at Sea HRAS 2020a, b), an NGO that works with seafarers including migrant fish workers, has raised concerns about the mental exhaustion of crew who remain out at sea, as workers are not able to stay in touch with or return to their families, and experience uncertainties associated with being at sea indeterminately. In an 
industry that is already known for sometimes severe labour abuse, this kind of added isolation at sea also raises concern regarding workers who may be more vulnerable to abusive employers. Vulnerability to abuse may also have further increased because of reduced monitoring (Saumweber et al. 2020), as fisheries management bodies waive requirements for on board observers who monitor compliance with fishing regulations (MSC 2020). While observers are not mandated to monitor working conditions and are themselves highly vulnerable workers, not just to potential infection but also to abuse and even murder (McVeigh 2020), their presence on a vessel may help constrain the abuse of fishing workers.

Quarantine measures are another issue. Migrant fish workers arriving at Taiwanese ports on industrial fishing vessels that are coming in for maintenance or offloading catch must undergo a mandatory 14-day quarantine on vessels or at hotels (as of mid-April 2020). Employers are required to pay for accommodations ("Virus Outbreak" 2020; Su-min et al. 2020), although it is unclear if workers are in reality quarantining on vessels so the employer bears no cost. As of June 3, there were no specific guidelines regarding quarantine measures. Another challenge is the entry into Taiwan of migrant fish workers from Southeast Asia on board vessels flying the flags of other countries, including the FOC mentioned above. These workers are considered to be entering Taiwan illegally, according to NGOs. In one case that took place in the spring of 2020, "more than 140 foreign fishers who entered Taiwan, reportedly on FOC vessels, were stranded in Kaohsiung's Cijin Port (旗津) as they did not have legal entry permits" (Chia-nan 2020). After a month, these workers were classified as illegal migrants and deported (Lin 2020). There was limited media coverage of this story, and it appears that support organizations were key for assisting and sheltering workers coming into ports on FOC vessels (Chia-nan 2020), as the government neglected these workers in their COVID-19 prevention efforts.

\section{Access to health care and emergency financial support}

By March 2020, the neglect of migrant worker populations in various low-paid sectors became apparent both globally, and within Thailand. This is when Singapore - a country that implemented an otherwise effective COVID-19 responsefaced a COVID-19 outbreak among migrant construction workers (Anukul 2020). News of other vulnerable worker populations being adversely impacted by COVID-19 appeared globally, in meat processing plants, among agricultural farm workers etc. In April 2020, Thailand faced a COVID-19 outbreak in a migrant detention centre in Songkhla province (The Nation 2020). These outbreaks made more visible some of the ways that migrant workers can be marginalized from access to health care and led to a push for better policy measures specific to migrant workers (see Fig. 1), both in Thailand and globally by organizations including the ILO (2020b). This increased visibility and the policy response are another way that the pandemic might have indirect benefits for migrant fish workers.

Since the initiation of policy reforms in 2014 (see Vandergeest and Marschke 2020), the Thai government has been able to register most fish workers under various schemes, meaning they have improved access to the public health system (Rogovin 2020a). The increased visibility of migrant worker marginalization induced the Thai government to recognize the public health importance of proactively reaching out to all migrant workers with specific health measures related to COVID-19. These included policies to ensure that migrant workers had access to free COVID-19 screening and treatment regardless of legal status. While these efforts no doubt helped prevent COVID-19 cases among fish workers, their effectiveness has been limited in ways that could have implications if community spread in Thailand returns. Migrant workers in Thailand are tied to their employers (this is how the worker registration process works), who are effectively responsible for their status and well-being. Thus, in the early days of the pandemic, the Thai government asked employers to keep an eye on the migrant workers in their employ, to ensure that they did not contribute to viral transmission (Sarunya 2020; The Nation 2020). Some reports (e.g. Fawthrop 2020, ILOb 2020) argue that it has been challenging for migrant fish workers to access health care or receive PPE due to uncertain legal status, lack of information and language barriers. Racism or xenophobia directed toward migrant workers in Thailand also constitutes a potential barrier to accessing health care. For instance, a wave of anti-migrant comments circulated in social media circles after media reports of the COVID-19 outbreak in Songkla's immigration detention facility (Charoensuthipan 2020).

Migrant workers in Thailand in principle have access to social security benefits and various COVID-19 compensation payments if they had lost work or face a reduced income if they had worked in Thailand for over six months and contributed to Thailand's Social Security Fund (IOM 2020). These include compensation and/or severance pay for employees who lost or quit jobs due to the pandemic, in amounts ranging from 45 to $75 \%$ of salaries depending on the specific circumstance. The Ministry of Labour set up a hotline for individuals unsure about their entitlements, and this hotline includes options to speak in Cambodian, Lao or Myanmar languages (IOM 2020). However, many workers may have missed the opportunity to take advantage of these programs because they left during initial chaotic period as these programs were being developed. As important, access to social security programs for migrant fish workers depends on boat owners filling out the paperwork (Ministry of Labor 2020). Seafarer support organizations have raised concerns on this issue, arguing that the Thai government should re-visit the requirement of boat 
owners being obliged to register fish workers to the Social Security Fund (งานวิจัย “ชีวิตติดร่างแห” ชีสวัสดิการแรงงานประมงดีขึ้น แนะดึงเข้าระบบประกันสังคม 2020 ). An ILO (2020b:7) report and a Thai CSO Coalition survey in 6 provinces during April (Siamhan and Triath 2020) confirm that migrant workers in fishing as well as agriculture and domestic work face barriers to accessing social security and support payments, either because of the dependency on employer enrolment, or because they are not documented. The Thai government also provided financial support policies for COVID-19-affected individuals of 5000 baht per monthprimarily farmers - but migrant workers are not eligible for these payments (ILOb 2020).

Legal status for migrant workers is tied to employment, rendering status precarious if employment becomes uncertain. Precarious legal status adds an additional layer of uncertainty for migrant fish workers and their access to services, especially in situations where workers reach the end of employment contracts, or lose the employment through which they obtained legal status. That said, the government has extended deadlines for renewing work documents, waived fees associated with overstay and altered pathways to obtain new documents in order to allow migrants to continue working and to change employers despite the closure of many government offices (IOM 2020; ILO Thailand 2020b:9; Issara Institute n.d.; มติชนสุดสัปดาห์ 2020). It is not clear, however, how aware fish workers are of these options, or whether there are barriers to accessing these policies.

Some NGO research suggests that fish workers have not been able to access basic information about the virus, how it spreads and safety measures. Up to $70 \%$ of workers have little knowledge about COVID-19, according to the Thai NGO Raks Thai (CARE Thai), while ILO Thailand (2020: 6) reports that a rapid assessment by the Migrant Working Group (an NGO group) found that almost all migrant workers reported that they were well informed about prevention and symptoms, but less so about what to do if they do have symptoms. Some workers have family in Thailand, and family members' access to information may be even more limited (CARE Thai, reported in the seminar 9 July). The lack of knowledge about COVID-19 among fish workers may be linked to limited dissemination and communication of information by the government in many ports, as many migrant fish workers do not speak Thai. Some government units have tried to address this limit. In the major fishing and seafood processing province of Samut Sakorn, the provincial public health office maintains a network of some 300 Burmese volunteers to assist with outreach and translation in hospitals (Narkvichien 2020), but it is unlikely that this effort was replicated across the many ports that are home to fishing vessels. Inadequate communication can also result in the spread of false information that endangers fish workers and increases feelings of anxiety and panic about migrant fish workers, as was seen among construction workers in Singapore (Zhuo
2020). The NGO coalition interviews found that support organizations are playing an important role with migrant fish workers in disseminating information about COVID-19 and government policy in the languages of the workers (Rogovin 2020a), although such organizations can only extend their reach so far (Siamhan and Trirath 2020).

Moving on to the Taiwanese case, government policy is that registered migrant workers, including EEZ fish workers, have access to public health care. In practice, however, fish workers go through the local labour recruitment agency that arranged their job if they want to visit a doctor or hospital. Our interviews conducted prior to the pandemic indicate that very few workers ever went to see a doctor or visited the hospital under these conditions. Although all EEZ fishers have the national health insurance cards required to purchase masks as part of Taiwan's PPE rationing measures, in the early months of the pandemic, workers reported that it was difficult for them to get the time off work necessary to wait in long queues at their local pharmacies (Yen 2020a). In February 2020, a migrant support organization in Yilan port, a significant port for the EEZ fishery, handed out over 1000 masks (Lin 2020) to workers on fishing vessels. The Taiwanese government disseminated awareness about COVID-19 to migrant workers through instructional materials translated into various languages (Aspinwall 2020), but support organizations report that employers and labour agencies offered limited assistance in the provision of information or supplies (Yen 2020a).

The 2017 labour regulations for DWF vessels registered in Taiwan require employers to purchase private health insurance for workers, yet they are often found to not comply (Chengchung et al. 2020). Should workers on DWF vessels become infected with COVID-19, or face other serious health issues, it is unclear where and how they might be treated. This situation is even worse for workers on vessels that are stuck at sea, unable to enter ports (Saumweber et al. 2020), and for vessels owned and operated from Taiwan but flagged to other countries, as they are not covered by the 2017 regulations. Even if vessels enter ports in Taiwan, workers may not have the ability to purchase masks when they arrive at port or access medical care if they do not have the appropriate health insurance (Wong 2020).

With respect to social security and financial support for COVID-affected workers: To our knowledge, fish workers did not lose their jobs although the number of hours worked was likely affected, increasing or decreasing depending on how pandemic management policies impacted demand for specific products. Unlike Thailand, wages in both the Taiwan EEZ and DWF fisheries are set up as a monthly wage specified in multi-year contracts, with government regulations on minimum wages as the basis, although some workers make more than minimum. At the same time, the fishing industry is effectively exempted from paying overtime, and workers experience many unreasonable deductions, with DWF workers being especially vulnerable to these deductions (Greenpeace 
East Asia 2020; EJF 2020; Vandergeest and Marschke under review). Nevertheless, it is likely that worker income was not affected if the hours worked increased or decreased; the main issue arises when a worker finishes a contract. To this end, the Taiwanese government granted automatic one-month visa extensions for all migrant workers, starting in March 2020 and continuing until June 2020, at which point workers could apply for a three-month extension (Everington 2020). For DWF workers, continual contract extensions are likely associated with being stuck at sea, as discussed in the previous section.

With respect to financial support for migrant workers: Taiwan has set up an economic stimulus voucher program to help offset the economic impacts of COVID-19, with Taiwan nationals and their 'foreign' spouses able to buy vouchers worth NT\$3000 (about US \$100) for NT\$1000, starting July 15 . However, migrant workers were excluded from this program, provoking criticism from advocacy groups who argued this was an opportunity for Taiwan to showcase how to treat migrant workers (Yen 2020b). Advocates argue that the exclusion of migrant workers from these and other policy measures may lead to further marginalization (Yen 2020b).

The challenges faced by migrant fish workers during the pandemic in Taiwan have been compounded by additional experiences with discrimination. For example, the media has reported arguments that Taiwanese citizens should be the first to get medical care or have access to medical supplies (Aspinwall 2020; Hioe 2020). Other reports mentioned that migrant workers were being accosted by Taiwanese citizens for not wearing masks in public (Cheung 2020), while a ban on sitting on the floor of Taipei's extensive main railway station was perceived by migrant worker organizations as targeting them and their public presence. Additional insights into the systemic barriers and racism facing migrant workers in fishing specifically would require follow-up discussions with migrant fish workers in the EEZ and DWF.

\section{Discussion and conclusions}

The 2020 coronavirus pandemic crisis has particularly impacted already-marginalized migrant workers (Gamlen 2020). The problems faced by migrant fish workers reflect those faced by migrant workers more generally, including vulnerability to changing economic conditions, access to health care, social security, racism and legal status (Baniya et al. 2020; Guadagno 2020, see also ILO 2020a). These challenges are further intensified by the isolation associated with working at sea, and the inherently crowded working and living conditions found on vessels.

Migrant fish workers in industrial fishing have long been highly vulnerable to health and safety concerns, abusive working conditions, poor pay and unreasonable deductions from wages (EJF 2019; Greenpeace East Asia 2020). The COVID-
19 pandemic has further intensified the vulnerabilities facing these workers. Migrant fish workers live and work in conditions that are conducive to the spread of infection; their legal status may be tied to employment leaving them undocumented or in an ambiguous status situation if they lose their jobs; and they rely on being able to travel across international borders both to get to their workplace and to return after completion of contracts, loss of employment, or when seeking to escape abusive work situations (Vandergeest and Marschke 2020). Our review of the news and media during the past months of the COVID-19 pandemic revealed three intersecting areas where migrant fish workers working in Thailand and Taiwan are experiencing heightened vulnerabilities: (1) employment disruptions due to seafood system instabilities; (2) travel or mobility restrictions; and (3) poor access to services such as health care or social programs. Let us examine each in turn.

First, employment in fisheries has been impacted by COVID19. The pandemic has destabilized the seafood industry in a variety of ways, increasing demands for some products, reducing demand for others. The movement of seafood through supply chains has further been disrupted by pandemic management policies. Instability continues due to rapid shifts in COVID-19 management - for example, restaurants may open, then shut again, processing facilities may stop and restart operation, curfews may be imposed, lifted, and re-imposed, and so on. We found reports of fish workers being out of work, working extended hours, or wanting to return to fish work but being unable to do so. All this renders fish work increasingly unstable and precarious as the pandemic continues.

Second, travel restrictions on both vessels and the movement of workers have created many difficulties for workers. Many cannot return to their home countries, and there are restrictions on port access and also access to services and support organizations in ports, leaving workers more vulnerable to abusive captains and owners. COVID-19 has highlighted inconsistencies in how governments addressed these disruptions especially in relation to workers in different kinds of fisheries. Workers in domestic or EEZ fisheries were beneficiaries of policies that extended visas (in Taiwan) or eased restrictions on mobility (in Thailand), but workers in DWF fisheries are often left in limbo, stranded in ports around the world, or even in Taiwan, without the benefits of policies aimed at domestic migrant workers.

Third, throughout this pandemic, migrant fish workers experienced barriers to public health care and COVID-19 testing. Many governments belatedly realized that they cannot neglect migrant workers in the management of the COVID19 pandemic, and the Thai and Taiwanese governments have been relatively proactive in extending health and safety protocols to migrant fish workers, with Thailand's government and civil society groups perhaps being more proactive. Even so, media and NGO accounts suggest that policies designed to reach these workers are undermined by a lack of 
understanding of the situation of the workers, by language barriers, and by the dependency of workers on employers or labour agencies for continued employment and legal statusthat is, by the material and lived conditions of being a migrant worker. These marginalizations from benefits are more extreme for workers in Taiwan's DWF. Limited access to information, health care and social security has often been heightened by racism - a vulnerability shared by migrant workers globally (Hennebry et al. 2020). In the case of fisheries, migrant workers are also men, which heightens the sense that they are a threat to security, including health security.

By examining two important flag state fleets that supply markets in regional and global seafood systems, we reveal some of the challenges that have emerged or intensified for migrant fish workers during the pandemic, reflecting how COVID-19 has impacted a sector that tends to be invisible. A series of other themes that we could only glimpse in our distanced research warrant discussion: these are questions that we cannot answer unless we are able to speak directly with workers.

First, we are unclear how COVID-19 has impacted everyday working conditions, with the exception of longer times at sea in the DWF, particularly since physical distancing on boats and mask-wearing at sea are next to impossible. Is there something different about the at-sea or at-port experience for workers? How many workers lost work and income, for how long, and if they lost income, were they able to access social security? Related to this is the question of living conditions including access to health care, already crucial for workers in this dangerous and unhealthy occupation but heightened due to the pandemic and pandemic control policies. For example, if migrant workers begin to re-enter Thailand without documentation, as some accounts suggest they might be, they may be reluctant to access health care or get tested for COVID-19, even when policy is in place to cover illegal migrants. And if vessel owners cannot find enough workers, will more of them start to adopt practices designed to tie workers to their employment such as debt, delayed payment of wages, manipulation of employerbased registration and even physical confinement?

A second theme that requires more exploration is that of worker knowledge about COVID-19 and pandemic policies and of worker individual and collective actions to reduce their vulnerability to both. While NGOs have reported that workers often do not have accurate information about COVID-19 (how it is transmitted, symptoms, risks etc.), or of pandemic control policies and policies intended to help negatively affected workers, we do not know much about how workers actually access information - do they obtain information largely through social media like Facebook? Government messaging on radio, TV, posters etc.? NGO outreach? Relatedly, we know very little about what they know about COVID-19, or the measures they are taking to protect themselves. With respect to NGOs: seafarer support organizations often step in as 'flanking' organizations who can provide services that are not accessible when provided by the government-including the provision of food to unemployed workers, the dissemination of information about COVID19 and how to protect oneself, and legal services. We know these organizations have been active during this time, but further insights are necessary concerning their reach (how many ports, number of workers), and effectiveness. This kind of knowledge might also help produce a better understanding of how fish workers share information, and about advocacy and organizing for improved living and working conditions more broadly.

Finally, in contrast to our analysis of the problems faced by migrant fish workers, we have also noted how the pandemic might also provide new opportunities for what is being labelled 'building back better' by improving working conditions, and facilitating access to public services for migrant fish workers. For example, restrictions on the movement of workers have led to labour shortages, which may enable workers to negotiate higher wages and better working conditions. The pandemic has made more visible how migrant workers in general, and fish workers specifically, have long been marginalized in a variety of ways, from access to health services to having to endure working and living conditions that would not be acceptable for most terrestrial work. It is possible that the attention to migrant worker access to public health care and social security may last after the pandemic is over. The new public visibility of these problems, and the realization that poor working and living conditions among migrant fish workers are a public health problem, could lead to more permanent policies that could lead to improvements for workers, including stronger and more appropriate regulatory action. These policies would hopefully involve dialogue with worker organizations (ILO 2020a: 6) and facilitate workers' ability to negotiate with employers for better working and living conditions, individually and collectively, so that workers can contribute to determining what improvements are most important.

\section{Compliance with ethical standards}

Conflict of interest The authors declare that they have no conflict of interest.

\section{References}

Anukul. 2020. Thai companies urged to tighten up Covid-19 measures for migrant workers. The Thaiger, 22 April. https://www.thethaiger. $\mathrm{com} /$ coronavirus/thai-companies-urged-to-tighten-up-covid-19measures-for-migrant-workers

Aqorau, T. 2020. COVID-19 and its likely impact on the tuna industry in the Pacific Islands. Devpolicy Blog from the Development Policy Centre. https://devpolicy.org/covid-19-and-its-likely-impact-on-thetuna-industry-in-the-pacific-islands-20200427-1/.

Aspinwall, N. 2020. Calls for amnesty as undocumented worker in Taiwan contracts the coronavirus The Diplomat, 29 February. https://thediplomat.com/2020/02/calls-for-amnesty-asundocumented-worker-in-taiwan-contracts-the-coronavirus/ 
Atuna. 2020. Ecuadorian Seiner's Newar entire crew infected with COVID-19, 27 May

Baniya, J., S. Bhattarai, B. Thapa, and V. Pradhan. 2020. COVID-19 and Nepali labour migrants research paper. Center for the Study of Labour and Mobility.

Barndt, D. 2004. Women working the NAFTA food chain: women, food and globalization. Canadian Scholars' Press.

Basok, T., and George, G. 2020. Migrant workers face further social isolation and mental health challenges during the coronavirus pandemic. The Conversation, 26 April. https://theconversation.com/ migrant-workers-face-further-social-isolation-and-mental-healthchallenges-during-coronavirus-pandemic-134324

Belton, B., M. Marschke, and P. Vandergeest. 2019. Fisheries development, labour and working conditions on Myanmar's marine resource frontier. J Rural Stud 69: 204-213.

Bismonte, C. 2020. The disproportionate effect of COVID-19 on migrant workers in ASEAN. The Diplomat, 22 May. https://thediplomat. com/2020/05/the-disproportionate-effect-of-covid-19-on-migrantworkers-in-asean/

Campling, L., and A. Cólas. 2021. Capitalism and the Sea. London/New York: Verso.

Campling, L., E. Havice, and P. Howard. 2012. The political economy and ecology of capture fisheries: market dynamics, resource access and relations of exploitation and resistance. J Agrar Chang 12: 177203.

Campling, L., A. Lewis, and M. McCoy. 2017. The tuna longline industry in the western and central Pacific Ocean and its market dynamics. Honiaria: Pacific Islands Forum Fisheries Agency.

Charoensuthipan, P. 2020. Migrants take hardest virus hit. Bangkok Post, 27 May. https://www.bangkokpost.com/thailand/general/1924636/ migrants-take-hardest-virus-hit

Cheng-chung, W., Hsiung-feng, C., Su-ming, Y., and Yeh, J. 2020. Control Yuan demands labor insurance coverage for all migrant fishermen. Focus Taiwan, 8 April. https://focustaiwan.tw/society/ 202004080023

Cheung, H. 2020.Virus prevention for the exploited. Taipei Times, 2 March. https://www.taipeitimes.com/News/feat/archives/2020/03/ $02 / 2003731902$

Chia-nan, L. 2020. Advocates urge action on FOC boats. Taipei Times, 3 June. https://www.taipeitimes.com/News/taiwan/archives/2020/06/ $03 / 2003737539$

Chiang, M. 2019. Human Rights at Sea baseline study on the awareness and application of human rights in Taiwan's fishing industry. Human Rights At Sea. https://www.humanrightsatsea.org/wpcontent/uploads/2020/06/HRAS_Baseline_Study_on_the Awareness_and_Application_of_Human_Rights_in_-Taiwans_ Fishing_Industry_October_2019 SP LOCKEED.pdf

Connolly, E. 2020. Concern as trawler crew get Covid-19. Southern Star, 13 May. https://www.southernstar.ie/news/concern-as-trawlercrew-get-covid-19-4205070

Couper, A., H.D. Smith, and B. Ciceri. 2015. Fishers and plunderers: theft, slavery and violence at sea. London: Pluto Press.

CSO Coalition. 2018. Falling through the net: a survey of basic labour rights among migrants working in Thailand's fishing sector. CSO Coalition for Ethical and Sustainable Seafood. http://ghre.org/2018/ 05/21/cso-coalition-falling-through-the-net/

CTN News. 2020. Thai fisheries imposes fishing ban on the Gulf of Thailand. Chiang Rai Times, 16 February. https://www. chiangraitimes.com/thailand-national-news/news-asia-thailand/ fishing/

Department of Fisheries, Government of Thailand. 2015. Marine fisheries management plan of Thailand: a national policy for marine fisheries management 2015-2019, Ministry of Agriculture and Cooperatives, Thailand. http://extwprlegs1.fao.org/docs/pdf/tha165156.pdf

Department of Fisheries, Government of Thailand. 2019. Thai Fishing Vessel Statistics Report No 8/2019
Department of Fisheries, Government of Thailand. 2020a. Marine capture production of commercial fisheries 2019 report (No. 5/2020).

Department of Fisheries, Government of Thailand. 2020b. การค้าสินค้าประมงของไทย เดือน พฤษภาคม 2563 . https://www. fisheries.go.th/strategy-tradestat/images/pdf/monthly/2563/May\% 2063.pdf

Derks, A. 2010. Migrant labour and the politics of immobilisation: Cambodian fishermen in Thailand. Asian Journal of Social Science 38(6):915-932

Divovich, E., Färber, L., Shon, S., Zylich, K. (2015). An updated catch reconstruction of the marine fisheries of Taiwan from 1950-2010. Fisheries Centre Working Paper 78. Fisheries Center, University of British Columbia: Vancouver, B.C.

EJF 2013. Sold to Sea: Human trafficking in Thailand's Fishing Industry. https://ejfoundation.org/reports/sold-to-the-sea-human-traffickingin-thailandsfishing-industry. Accessed 18 Aug 2020

EJF. 2019. Blood and water: human rights abuses in the global seafood industry. London: Environmental Justice Foundation.

EJF. 2020. Illegal fishing and human rights abuses in the Taiwanese fishing Fleet. London, UK: Environmental Justice Foundation. https://ejfoundation.org/resources/downloads/Taiwan-briefingIUU-HR-2020-July.pdf

Everington, K. 2020. Taiwan allows migrant worker employers to extend contracts amid pandemic. Taiwan News (10 June) https://www. taiwannews.com.tw/en/news/3945560.

Fawthrop, T. 2020. COVID-19: Thailand's looming second wave. The Diplomat, 1 June. https://www.thediplomat.com/2020/06/covid-19thailands-looming-second-wave/.

Fisher, D., A. Reilly, A.K.E. Zheng, A.R. Cook, and D.E. Anderson. 2020. Seeding of outbreaks of COVID-19 by contaminated fresh and frozen food. bioRxiv 2020.08.17.255166. https://doi.org/10. $1101 / 2020.08 .17 .255166$

Frantzeskou, E., O.C. Jensen, and A. Linos. 2016. Health status and occupational risk factors in greek small fisheries workers. International maritime health 67 (3): 137-143.

Gamlen, A. 2020. Migration and mobility after the 2020 pandemic: the end of an age? Centre on Migration, Policy and Society, University of Oxford. https://publications.iom.int/system/files/pdf/migrationand-mobility.pdf

Greenpeace East Asia. 2020. Choppy waters: forced labour and illegal fishing in Taiwan's distant water fisheries. Greenpeace East Asia. https://www.greenpeace.org/usa/wp-content/uploads/2020/03/ b87c6229-2020-choppy-waters-en.pdf

Greenpeace Southeast Asia. 2016. Turn the tide: human rights abuses and illegal fishing in Thailand's overseas fishing industry. Greenpeace Southeast Asia. https://storage.googleapis.com/planet4southeastasia-stateless/2019/04/a99d5300-a99d5300-turn-the-tide. pdf

Guadagno, L. 2020. Migrants and the COVID-19 pandemic: an initial analysis. International Organization for Migration (IOM). https:// publications.iom.int/system/files/pdf/mrs-60.pdf

Ha, K.O., K. Chia, and C. Jiao. 2020. Over 200,000 seafarers fear there's no plan to disembark them. Bloomberg (8 July) https://www. bloomberg.com/news/articles/2020-07-08/pregnant-and-stuck-ona-ship-in-the-middle-of-the-pandemic.

Haley, E., S. Caxaj, G. George, J.L. Hennebry, E. Martell, and J. McLaughlin. 2020. Migrant farmworkers face heightened vulnerabilities during COVID-19. Journal of Agriculture, Food Systems, and Community Development 9 (3): 35-39. https://doi.org/10. 5304/jafscd.2020.093.016.

Havice, E., and L. Campling. 2021. Industrial fisheries and oceanic accumulation. In The Edward Elgar Handbook of Critical Agrarian Studies, ed. H. Akram, K. Dietz, B. Engles, and B. McKay. (forthcoming) 
Havice, E., M. McCoy, and A. Lewis. 2019. Market and industry dynamics: western and central Pacific Ocean distant water tuna purse seine fishery. Honiara: Pacific Islands Forum Fisheries Agency.

Havice, E., M. Marschke, and P. Vandergeest. 2020. Industrial seafood systems in the immobilizing COVID-19 moment. Agric Hum Values 37: 655-656.

Heidler, S. 2020. Thailand lockdown: jobless and trapped migrant workers in limbo (video). Aljazeera, 22 May. https://www. aljazeera.com/news/2020/05/thailand-lockdown-jobless-trappedmigrant-workers-limbo-200522064857801.html

Hennebry, J., Caxaj, S., McLaughlin, J., and Mayell, S. 2020. Coronavirus: Canada stigmatizes, jeopardizes essential workers, The Conversation - Canada, 3 June. https://theconversation.com/ coronavirus-canada-stigmatizes-jeopardizes-essential-migrantworkers-138879

Herz, N. 2020. A Seattle fishing company has had more than 100 COVID-19 cases on its ships. They're heading to Alaska this summer. Alaska Public Media (9 June) https://www.alaskapublic.org/ 2020/06/09/a-seattle-fishing-company-has-more-than-100-covid19-cases-on-its-ships-theyre-heading-to-alaska-this-summer/.

Hioe, B. 2020. Questions about measures for migrant workers and foreigners living in Taiwan during COVID-19 epidemic. New Bloom Magazine, 3 March. https://newbloommag.net/2020/03/03/covid19-migrant-workers/

Hodal, K., Songkhla, C. K., and Lawrence, F. 2014. Revealed: Asian slave labour producing prawns for supermarkets in US, UK,The Guardian, 10 June. http://www.theguardian.com/globaldevelopment/2014/jun/10/supermarket-prawns-thailand-producedslave-labour

Howard, P.M. 2012. Sharing or appropriation? J Agrar Chang 12 (2-3): 316-343.

HRAS (Human Rights at Sea). 2020a. Seafarers continue to highlight their worries and concerns to Human Rights at Sea. Human Rights at Sea, 21 April. https://www.humanrightsatsea.org/2020/04/21/ seafarers-continue-to-highlight-their-worries-and-concerns-tohuman-rights-at-sea/

HRAS (Human Rights at Sea). 2020b. Fisheries observer deaths at sea, human rights $\&$ the role $\&$ responsibilities of fisheries organisations. 1 July. https://www.humanrightsatsea.org/wp-content/uploads/ 2020/07/HRAS_Abuse_of_Fisheries_Observers_REPORT_JULY2020_SP_OPTIMISED.pdf

HRW (Human Rights Watch). 2018. Hidden chains: rights abuses and forced labor in Thailand's fishing industry. https://www.hrw.org/ report/2018/01/23/hidden-chains/rights-abuses-and-forced-laborthailands-fishing-industry

International Labour Organization (ILO). 2013. Employment practices and working conditions in Thailand's fishing sector. Bangkok: ILO Regional Office for Asia and the Pacific

International Labour Organization (ILO). 2018. Ship to Shore Rights: Baseline research on fishers and seafood workers in Thailand. Bangkok: ILO Regional Office for Asia and the Pacific.

Hsiu-chuan, S., and J. Yeh. 2020. Indonesia-Taiwan close to deal on migrant workers: official. Focus Taiwan (13 May) https:// focustaiwan.tw/society/202007130019.

ILO. 2020a. Protecting migrant workers during the COVID-19 pandemic recommendations for policy-makers and constituents. Policy Brief (April 30) https://www.ilo.org/global/topics/labour-migration/ publications/WCMS_743268/lang\%2D\%2Den/index.htm.

ILO. 2020b. Endline research findings on fishers and seafood workers in Thailand. International Labour Organization (ILO), 10 March. https://www.ilo.org/asia/publications/WCMS_738042/lang\%2D\% 2Den/index.htm

ILO Thailand. 2020a. Country policy responses, COVID-19 and the world of work. International Labour Organization (ILO), 13 May. https://www.ilo.org/global/topics/coronavirus/country-responses/ lang\%2D\%2Den/index.htm\#TH
ILO Thailand. 2020b. COVID-19: impact on migrant workers and country response in Thailand. International Labour Organization (ILO), 3 July. https://www.ilo.org/wcmsp5/groups/public/\%2D\%2Dasia/\%2D\%2D-ro-bangkok/\%2D\%2D-sro-bangkok/documents/ briefingnote/wcms_741920.pdf.

IMO. 2020. 400,000 seafarers stuck at sea as crew change crisis deepens. International Maritime Organization, 24 September. https://www. imo.org/en/MediaCentre/PressBriefings/Pages/32-crew-changeUNGA.aspx

IOM. 2020. Tips for migrant workers whose job is affected by the COVID-19 pandemic. International Organization for Migration (IOM) Thailand, 31 March. https://thailand.iom.int/sites/default/ files/Infosheets/Info $\% 20$ Sheet $\% 20$-Migrant $\% 20$ Workers $\%$ 20 whose $\% 20$ job $\% 20$ is $\% 20$ affected $\% 20$ by $\% 20$ the $\% 20$ COVID19\%20pandemic_ENG.pdf

Issara Institute \& IJM. 2017. Not in the same boat: Prevalence and patterns of labour abuse across thailand's diverse fishing industry (Focus on labor issues in the fishing industry No. 2). 2017. https:// $\mathrm{d}$ o c s.w i x s t a t i c . c o m/ u g d / 5 b f 36 e 9ec3ea47011343158f7c76fc7f14591f.pdf

Jensen, O.C., G. Petursdottir, I.M. Holmen, A. Abrahamsen, and J. Lincoln. 2014. A review of fatal accident incidence rate trends in fishing. International maritime health 65 (2): 47-52.

Kaustell, K.O., T.E. Mattila, and R.H. Rautiainen. 2016. Occupational injuries and diseases among commercial fishers in Finland 19962015. International maritime health 67 (3): 163-170.

Kornreich, Y., and Y. Jin. 2020. The secret to Taiwan's successful COVID response. Asia Pacific Foundation of Canada (9 May) https://www.asiapacific.ca/publication/secret-taiwans-successfulcovid-response.

Lin, S. 2020. The migrant fishermen union on the frontlines against Covid-19 and bosses. The News Lens (24 June) https:// international.thenewslens.com/article/136920.

Marschke, M., and P. Vandergeest. 2016. Slavery scandals: Unpacking labour challenges and policy responses within the off-shore fisheries sector. Mar Policy 68: 39-46.

McVeigh, K. 2020. Disappearances, danger and death: what is happening to fishery observers? The Guardian, 22 May. https:/www. theguardian.com/environment/2020/may/22/disappearancesdanger-and-death-what-is-happening-to-fishery-observers

Mereghetti, M. 2020a. Ecuador shrimp, tuna processors endure despite lockdown, curfew. Undercurrent News, 25 March.

Mereghetti, M. 2020b. Bolton sees canned tuna sales boom in EU lockdowns Undercurrent News, 31 March.

Mereghetti, M. 2020c. Filipino canners hold on despite COVID-19 restrictions. Undercurrent News (3 April).

M in istry of L a b or ( Thailand). 2020. ประกาศกระทรวงแรงงานเรืองการจัดสิทธิประโยชน์ด้านสุขภาพและสวัสดิการแก่แรงงานประมง (translation: Notification of the Ministry of Labor regarding the arrangement of health and welfare benefits for fishery workers), No. 137, 5ง. http://www.ratchakitcha.soc.go.th/DATA/ PDF/2563/E/005/T_0030.PDF

MSC (Marine Stewardship Council). 2020. MSC sets out expectations on observer coverage. Marine Stewardship Council, 22 April. https:// www.msc.org/media-centre/briefings-statements/covid-19-mscsets-out-expectations-on-observer-coverage-during-derogationperiod.

Narkvichien, M. 2020. In Thailand's fishing and seafood processing capital, Burmese migrants get help to protect themselves from COVID19, World Health Organization, 15 July. https:/www.who.int/ thailand/news/feature-stories/detail/in-thailand-s-fishing-andseafood-processing-capital-burmese-migrants-get-help-to-protectthemselves-from-covid-19.

National News Bureau of Thailand. 2020. สำนักข่วแห่งชาติ: จ.สมุทรสาคร "ลุย" ตรวจหาเชื้อ COVID-19 เชิงรุกในแรงงานต่างด้าวเรือประมง : ข่าว,ข่าวสาร, 
ภูมิภาค,สถานการณ์,สือ. 2 May. https://thainews.prd.go.th/th/news/print news/TCATG200502120859532

Neef, A. 2020. Legal and social protection for migrant farm workers: lessons from COVID-19. Agric Hum Values 37: 641-642.

Rogovin, K. 2020a. COVID-19 impact on migrant workers in Thailand International Labor Rights Forum, 27 March. https://laborrights. org/blog/202003/covid-19-impact-migrant-workers-thailand

Rogovin, K. 2020b. Time for a sea of change. Why union rights for migrant workers are needed to prevent forced labour in the Thai seafood industry. Washington, D.C.: International Labour Rights Reform

Sarunya, S. 2020. แรงงา นพม่า ทยอยกลับ ไปหางานที่บ้านเกิด เผยไม่กลับมาไทยอีก เพรา ะค่าใช้จ่ายสูง. Astoryth, 29 May. http://www. astoryth.com/?p=7325

Saumweber, W., Lehr, A., and Loft, T. 2020. Covid-19 at Sea: impacts on the blue economy, ocean health, and ocean security. Centre for Strategic and International Studies, 10 April. https://www.csis.org/ analysis/covid-19-sea-impacts-blue-economy-ocean-health-andocean-security

Seaman, T. 2020. Thai Union Ghana cannery linked to cover 500 COVID-19 cases in country, Undercurrent News, 12 may.

Siamhan, P., and R. Trirath. 2020. Impacts of the COVID-19 pandemic on small-scale producers and workers: perspectives from Thailand's seafood supply chain. Oxfam. https://doi.org/10.21201/2020.6225.

Stringer, C., D.H. Whittaker, and G. Simmons. 2015. New Zealand's turbulent waters: the use of forced labour in the fishing industry. Global Networks 16 (1): 3-24.

Sui, C. 2020. In Taiwan the coronavirus is playing out very differently. What does life without a lockdown look like?. NBC News, April 23. https://www.nbcnews.com/news/world/taiwanese-authorities-stayvigilant-virus-crisis-eases-n1188781

Su-min, Y., Ming-hsuan, C., and Yi-ching, C. 2020. New quarantine measures for far-sea fishermen due next week. Focus Taiwan, 14 May. https://focustaiwan.tw/society/202005140017

Thaw, H. and Dunant, B. 2020. More migrants prepare to return, but is Myanmar ready this time? Frontier Myanmar, 17 May. https:// frontiermyanmar.net/en/more-migrants-prepare-to-return-but-ismyanmar-ready-this-time

The Nation. 2020. Govt asks employers to watch foreign workers for Covid-19 symptoms. The Nation Thailand, 26 April. https://www. nationthailand.com/news/30386802?utm_source=category\&utm medium=internal referral

Thongtub, E. 2020. Navy assures Phuket fishing fleet clear of COVID19. The Phuket News, 17 April. https://www.thephuketnews.com/ navy-assures-phuket-fishing-fleet-clear-of-covid-19-75741.php

Tickler, D., J.J. Meeuwig, K. Bryant, F. David, et al. 2018. Modern slavery and the race to fish. Nature communications 9 . https://doi. org/10.1038/s41467-018-07118-9.

Twining, G. 2020. COVID-19: Industry figures call for seafarer access to emergency medical assistance ashore. Safety at Sea, 21 May. https:// safetyatsea.net/news/2020/covid-19-industry-figures-call-forseafarer-access-to-emergency-medical-assistance-ashore/

Tzu-ti, H. 2020. Over 80,000 migrant workers in Taiwan stay put amid pandemic. Taiwan News (13 July) https://www.taiwannews.com. tw/en/news/3965610.

Urbina, I. 2015. 'Sea slave': the human misery that feeds pets and livestock. The New York Times, 27 July.
Vandergeest, P., and M. Marschke. 2020. Modern slavery and freedom. Antipode 52: 291-315.

Vandergeest, P., and M. Marschke. Under review. Beyond 'slavery scandals': explaining working conditions among fish workers in Taiwan and Thailand. Mar Policy.

Venugopal, V. 2020. The shore scene: the heavy toll of COVID-19 on India's fishers. THE BASTION, 5 May. https:/thebastion.co.in/ politics-and/the-shore-scene-the-heavy-toll-of-the-covid-19-onindias-fishers/

Virus outbreak: fishing boats that anchor abroad set to be quarantined. 2020. Taipei Times, 4 April. https://www.taipeitimes.com/News/ taiwan/archives/2020/04/04/2003733985

Wong, L. 2020. Can migrant workers buy masks under the real name system? [blog post]. 4 February. https://ydwong.wordpress.com/ 2020/02/04/1-2/ [translated].

Xinhua News Agency. 2020. Fishing boats seek 50,000 workers as virus spurs migrants to leave. Khaosod English (10 May) https:/www. khaosodenglish.com/news/crimecourtscalamity/2020/05/10/ fishing-boats-seek-50000-workers-as-virus-spurs-migrants-toleave/

Yen, W. 2020a. Migrant fishermen seek support from government amid COVID-19 pandemic. Focus Taiwan (4 April) https://focustaiwan. tw/society/202004040017.

Yen, W. 2020b. Priests urge inclusion of migrant workers in stimulus voucher program (2020, June 5) Focus Taiwan, 5 June. https:// focustaiwan.tw/society/202006050015

Zaw, S.M.M. 2020. Over 200 migrant workers returning from Bangkok under plan of Myanmar embassy. Mizzima Myanmar News and Insight (23 May) http://www.mizzima.com/article/over-200migrant-workers-returning-bangkok-under-plan-myanmarembassy.

Zhuo, T. 2020. Coronavirus: worker ambassadors help migrant worker Centre fight fake news. The Straits Times (7 March) https://www. straitstimes.com/singapore/manpower/coronavirus-workerambassadors-help-migrant-worker-centre-fight-fake-news.

งานวิจัย “ชีวิตติดร่างแห” ชีสวัสดิการแรงงานประมงดี ขึ้น แนะดึงเข้าระบบประกันสังคม. 2020. Thaipublica, 9 July. https:// thaipublica.org/2020/07/fisheries-labour-welfare-improving-report/

จับ44แรงงานพม่าลอบเข้าเมือง. 2020. Post today, 18 July. https://www. posttoday.com/social/local/100204

นายจ้างขอรัฐูแบ่งเบา ค่าตรวจโรค-กักต้ว นำเข้าแรงงานเพือนบ้าน'. 2020 . 'นนายจ้างขอรัรูแบ่งเบา ค่าตรวจโรค-กักตัว นำเข้าแรงงานเพือนบ้าน'. Tcijthai, 26 July. https://www.tcijthai.com/news/2020/7/scoop/ 10722.

มติชนสดสัปดาห์. 2020 . ประมงอ่วมพิษโควิด คนงานหาย 5 หมื่น ไฟเขียวรับแรงงานข้ามชาติขึนเรือ. มดิชนสุดสัปดาห์, 8 May. https://www. matichonweekly.com/hot-news/article_302879

มติประชุมใหญ่ เลิกอาชีพประมง". 2020. Thansettakij, 20 August. https:// www.thansettakij.com/content/Macro_econ/446213

ลูกเรือประมง 22 ชีวิตกลับจากออกเรือหาปลาในมาเลเซีย ยอมกักตัวเอง 14 วัน. 2020. Thai Post | อิสรภาพแห่งความคิด, 4 April. https://www. thaipost.net/main/detail/62064

Publisher's note Springer Nature remains neutral with regard to jurisdictional claims in published maps and institutional affiliations. 